\title{
Fate of pharmaceuticals and personal care products in wastewater treatment plants - Conception of a database and first results
}

\author{
C. Miège, J.M. Choubert, L. Ribeiro, M. Eusèbe, M. Coquery \\ Cemagref, Water Quality and Pollution Control Research Unit, 3 bis quai Chauveau, CP 220, F-69336 Lyon, France \\ Corresponding author : cecile.miege@cemagref.fr
}

By means of a database including information from 117 international scientific papers, we present quantitative conclusions on the concentrations, frequencies of detection and removals of pharmaceutical products in wastewater treatment plants.

\begin{abstract}
We created a database in order to quantitatively assess the occurrence and removal efficiency of pharmaceuticals and personal care products (PPCPs) in wastewater treatment plants (WWTPs). From 117 scientific publications, we compiled 6641 data covering 184 PPCPs. Data included the concentrations of PPCPs in WWTP influents and effluents, their removal efficiency and their loads to the aquatic environment. The first outputs of our database allowed to identify the most investigated PPCPs in WWTPs and the most persistent ones, and to obtain reliable and quantitative values on their concentrations, frequency of detection and removal efficiency in WWTPs. We were also able to compare various processes and pointed out activated sludge with nitrogen treatment and membrane bioreactor as the most efficient ones.
\end{abstract}

Keywords: database; pharmaceuticals; personal care products; removal efficiency; wastewater treatment plants

\section{INTRODUCTION}

The concern for pharmaceuticals and personal care products (PPCPs) as toxic substances in the environment and the need to assess their environmental risk have greatly increased since the early nineties. Several reviews dealing with the exposition and effect of pharmaceuticals have been published recently (Halling-Sorensen et al., 1998; Daughton and Ternes, 1999; Jorgensen and Halling-Sorensen 2000; Kümmerer, 2001; Ternes et al., 2001; Heberer, 2002; Petrovic et al., 2003; Larsen et al., 2004; Janex-Habibi et al., 2004; Jones et al., 2004; Kuster et al., 2004; Zwiener and Frimmel 2004; Garric and Ferrari, 2005; Hernando et al., 2005; Fent et al., 2006; Zuccato et al., 2006). These reviews allow to identify more than one hundred pharmaceuticals and personal care 
products from various prescription classes measured in WWTPs in several European countries, Brazil and North America. These PPCPs include analgesics and anti-inflammatory drugs, antibiotics and bacteriostatics, antiepileptics, betablockers, blood lipid regulators, contrast media, cytostatics, hormones (including oral contraceptives), antidepressants and anxiolitics, musk fragrances, disinfectants and antiseptics. These reviews outline the exposure routes to the aquatic and soils environment for different classes of drugs (Halling-Sorensen et al., 1998; Jorgensen and Halling-Sorensen 2000; Kümmerer, 2001; Heberer, 2002), the environmental risk assessment strategy (Daughton and Ternes, 1999; Jones et al., 2004; Garric and Ferrari, 2005; Hernando et al., 2005; Fent et al., 2006; Zuccato et al., 2006). Some authors listed the annual quantities of PPCPs prescribed for different countries (Halling-Sorensen, 1998; Jorgensen and Halling-Sorensen 2000; Fent et al., 2006). Two papers summarised the modes of action of PPCPs in humans and mammals (Fent et al., 2006) and their metabolization in humans (Richardson and Bowron 1985). A few reviews deal with their effect and concentration in aquatic vertebrates and invertebrates (HallingSorensen, 1998; Daughton and Ternes, 1999; Jones et al., 2004; Fent et al., 2006). The analytical protocols to identify and quantify PPCPs in environmental matrices have also been scrutinized (Ternes et al., 2001; Petrovic et al., 2003; Kuster et al., 2004; Zwiener and Frimmel 2004). Several papers present ranges of PPCPs concentrations in various compartments of the aquatic environment and in wastewaters (Halling-Sorensen, 1998; Daughton and Ternes, 1999; Kümmerer, 2001; Heberer, 2002; Garric and Ferrari, 2005; Fent et al., 2006). Finally, a few papers present and compare the various processes used in WWTPs to eliminate PPCPs (Janex-Habibi et al., 2004; Larsen et al., 2004). Larsen et al. (2004) presented the source separation approach, which consists of pre-treatment of highly contaminated sources such as urines or wastewaters from hospitals.

However, we noted that the reviews dealing with the occurrence of PPCPs in wastewaters and their removal efficiency could not reach quantitative conclusions as they did not use a database to collect and process data from the literature.

Our objective in this study was to obtain reliable and quantitative information on PPCPs concentrations and removal efficiency and to study if existing data extracted from the literature permitted to establish trends on PPCPs removal efficiency for some processes or operating parameters.

We considered PPCPs used for human treatments and included antiseptics, hormones and personal care products. For the most studied PPCPs, we were able to compute mean and median liquid influent and effluent concentrations, mean removal efficiency, and we calculated minimum and 
maximum values, and relative standard deviations. We also studied the influence of the type and the operating conditions of WWTPs in order to explain and to predict the fate of these contaminants in WWTPs.

\section{DESCRIPTION OF THE DATABASE}

We built our database from the compilation of 115 international research papers and 2 French research reports covering a period from January 1997 to June 2006 for international studies and from 1997 to February 2007 for French studies. These 117 scientific publications are reported in annex 1. We considered all pharmaceuticals used for human treatment and included hormones, antiseptics and personal care products (musk fragrances, sun-screen agents and insect repellents). The total number of molecules covered in the database reaches 184 .

We recorded 6641 data from the literature including concentrations in influents (1602 data), concentrations in effluents (3120 data), loads of compounds $(\mathrm{kg} / \mathrm{d})$ to be treated in influents $(115$ data), loads released in the environment by effluents (186 data) and removal efficiency (1618 data) for the dissolved aqueous compartment of WWTPs. In this paper the removal of PPCPs in the dissolved phase is referred to as $\mathrm{R}$.

In our database, values of R obtained with activated sludge processes (ASP) are well documented, with 742 data for the high sludge retention time configuration for nitrogen removal, 129 data for the low sludge retention time configuration for carbon removal, 185 for ASP with phosphorus treatment (and also nitrogen treatment for some of these 185 WWTPs). We also recorded R for other types of processes: membrane bioreactors with nitrogen treatment (63 data), pre-treatment and primary sedimentation tanks (49 data), fixed biomass systems (immerged biofilters, biodiscs and trickling filters, 18 data) and waste stabilization ponds (14 data).

To reach quantitative conclusions, we only considered concentrations and $\mathrm{R}$ in the dissolved phase of WWTPs as too few data are available for sludges and suspended solids. Only data obtained from $24 \mathrm{~h}$ flow proportional composite sample were compiled, as it is the only way to obtain a sample representative of the wastewater that enter the treatment plants. When available, we favoured individual values of concentration or R. Nonetheless, we decided to use also mean values when the number of individual values was mentioned in the original paper so we could weight these mean values. 
When it was available, we recorded detailed information on the WWTPs: design capacity (mean flow rate in $\mathrm{m}^{3} / \mathrm{d}$ and population equivalent); nature of influent (municipal, dry or wet weather influent, industrial, hospital); type of treatment (primary, secondary and tertiary stages); temperature and $\mathrm{pH}$ of the mixed liquor in the biological reactor; volume of the reactor; hydraulic and sludge retention times; physico-chemical characteristics of wastewaters (e.g., chemical oxygen demand and suspended solid concentration).

The sampling and analytical procedures were also documented in detail if available: period of the year (month or season, year), sampling type (grab, time or flow proportional), nature of the sample (raw sewage, pre-treatment effluent, primary, secondary or tertiary effluents), water fraction analysed (dissolved, particular, raw or total), description of the analytical method (extraction and purification steps, chromatographic analysis, use of internal standards), and description of the performances of the analytical method (recovery, relative standard deviation, limits of detection and quantification). But this information is rarely described in a comprehensive manner in papers dealing with pharmaceuticals occurrence in WWTP. Therefore, at this stage, it cannot be a selection criteria since it would have led us to suppress most of the available data from our analysis. This aspect will be the subject to a following publication dealing with the difficulty to assess the reliability of data in scientific papers on PPCPs in WWTPs.

\section{RESULTS AND DISCUSSION}

\section{The PPCPs the most investigated in WWTPs}

The molecules and the therapeutic classes the most investigated in WWTPs are reported in Table 1. The frequency of citation for each molecule was calculated as the ratio of the number of data recorded in the database for a given molecule over the total number of data for all studied molecules. We then compiled this information for each therapeutic class for the $80 \%$ most frequently cited molecules. The results show that the therapeutic classes the most cited in our database are hormones (30\%, 7 molecules), analgesics and antiinflammatories (20\%, 5 molecules) and antibiotics (9\%, 7 molecules). Estrone and 17 $\beta$-estradiol are the most investigated molecules (553 and 543 data respectively, 8\%). The lipid regulators, anti-epileptics, metabolites, betablockers, personal care products and contrast products cited in Table 1 have citation frequencies between 1 and $5 \%$. For all other molecules, the frequency of citation is below $1 \%$. 
Thus, 33 molecules represent $80 \%$ of the recorded data. They have been investigated because they are highly prescribed and continuously discharged in the environment, and could be potentially toxic. For the other PPCPs (151 molecules), more limited information is available: e.g., citation frequency of only $0.6 \%$ for paracetamol and $0.3 \%$ for aspirin, bisoprolol and sotalol.

\section{Concentrations of PPCPs in the dissolved phase of WWTP influents and effluents}

The collected data covered influent and effluent concentrations for ASP combined with a pretreatment, which could be associated, depending on the WWTP, with a primary sedimentation tank, a treatment of nitrogen and / or phosphorus, or a tertiary treatment. For all studied molecule, we calculated the mean, median, relative standard deviation (RSD), minimum and maximum concentrations of PPCPs in influent and effluent of WWTPs. For this calculation, we did not use values from pilot or batch experiments. The results are presented in Table 2 (in alphabetic order of molecule by therapeutic class). We only reported the results for the molecules for which a minimum of 3 concentration data were recorded for influent or for effluent. This represents a total of 43 molecules for influent concentrations and 43 molecules for effluent concentrations.

Generally, the frequency of quantification in influent and effluent is above $90 \%$ for a majority of molecules. Mean dissolved concentrations in the influent range from $4 \mathrm{ng} / \mathrm{L}$ for $17 \alpha$-ethinylestradiol (detected in $91 \%$ of the influent samples) to $212 \mu \mathrm{g} / \mathrm{L}$ for salicylic acid (detected in $100 \%$ of the influent samples). Salicylic acid may be a metabolite of acetylsalicylic acid, but there are several other possible sources of salicylic acid. The lowest influent concentrations quantified (ng/L level) are found for the hormones and the highest measured concentration (above $292 \mu \mathrm{g} / \mathrm{L}$ ) are recorded for some analgesic-antiinflammatory (naproxen and paracetamol) and a metabolite (salicylic acid). These influent concentrations depend mainly on the degree of prescription and human metabolization.

Mean dissolved concentrations in the effluent range from $0.8 \mathrm{ng} / \mathrm{L}$ for $17 \alpha$-estradiol (detected in $64 \%$ of the effluent samples) to $5.7 \mu \mathrm{g} / \mathrm{L}$ for iopromide (detected in $57 \%$ of the effluent samples). As for the influent, we observe that the lowest quantified concentrations are found for hormones (around $0.1 \mathrm{ng} / \mathrm{L}$ ) and the highest ones for analgesic-antiinflammatory (25 and $34 \mu \mathrm{g} / \mathrm{L}$ for ibuprofen and naxopren, respectively).

RSD are between $10 \%$ and $150 \%$. Some higher RSD (up to 365\%) are found for 2 antiinflammatories (naproxen in influents and effluents, ibuprofen in effluents), 3 hormones (17 eethinylestradiol in influents, 17ßestradiol and estriol in effluents) and 1 lipid regulator 
(bezafibrate in effluents). These ranges of RSD values are mainly resulting from the large number and variety of WWTPs considered in these papers.

\section{Removal of PPCPs in the dissolved aqueous phase of WWTPs}

In the literature, the removal efficiency is generally computed as the percentage of reduction between the dissolved aqueous phase concentration of the contaminant in the influent and the dissolved aqueous phase concentration of the contaminant in the effluent. Except for a few recent studies, PPCPs concentrations in sludge or suspended solid are generally not considered nor measured, probably because of the difficulty to sample and to analyse such complex matrices. Only 15 publications, over the 117 publications studied, reported PPCPs concentrations in sludges and 1 in suspended solid. None of the 117 papers reported removal obtained taking into account both liquid and solid (sludges and suspended solids) compartments of WWTPs.

In order to compute statistics on $\mathrm{R}$ in the dissolved aqueous phase for the different molecules studied, we used results on $\mathrm{R}$ from our database with the following conditions: for measured and also calculated R from influent and effluent concentrations (if measured in the same WWTP); for full scale WWTP and pilots WWTP, but not for batch experiments; excluding negative values of R.

\section{Removal for ASP for the studied molecules}

We calculated mean R and RSD for WWTPs with ASP in order to evaluate the persistence of the studied PPCPs.

The collected data of R concerned ASP combined with a pre-treatment stage, which could be associated, depending on the WWTP, with a primary sedimentation tank and/or a treatment of phosphorus. Two types of ASP were considered: the ones that perform carbon removal (sludge age $<10 \mathrm{~d}$ ), and the others that perform nitrogen removal (sludge age $>10 \mathrm{~d}$ ).

Mean values of $\mathrm{R}$ could be calculated for 50 molecules and the data set was equal to or above 3 for 32 molecules (Figure 1). Considering molecules with a minimum data set of 3, we could point out triclosan, norfloxacin, $17 \beta$-estradiol and estriol as highly removed contaminants ( $\mathrm{R}>80 \%$ ), whereas atenolol, carbamazepine, metoprolol, trimetoprim, mefenamic acid and clofibric acid have low removal efficiency $(\mathrm{R}<30 \%$ ). The RSD are quite variable, ranging from 22 to $143 \%$ (mean $\mathrm{RSD}=43 \%$, median $\mathrm{RSD}=39 \%, \mathrm{n}=32$ ) for the different molecules (for those with a data set higher $\geq$ 3). This variability could be mainly attributed to the variety of WWTPs from various countries considered. Nonetheless, the available database, coupled with a thorough data screening procedure, 
succeeded to establish a relatively robust data set on $\mathrm{R}$ (dissolved fraction) for activated sludge treatment for these 32 molecules.

The main mechanisms involved in removal efficiency of PPCPs are biodegradation (e.g., oxidation, hydrolysis, demethylation, cleavage of glucuronide conjugates), sorption on sludge or particulate matter (by hydrophobic or electrostatic interactions), filtration and chemical oxidation. Loss by volatilization can be considered as negligible for PPCPs except for musk fragrances, which are slightly volatile (Larsen et al., 2004).

\section{Influence of the type of process on $R$ values}

According to our results, the type of WWTP process significantly influences R of PPCPs.

We computed mean $\mathrm{R}$ value for each molecule for the various studied processes ( $\mathrm{y}$ axis) and plotted them against mean $\mathrm{R}$ value calculated for the same molecules for the ASP with nitrogen removal ( $\mathrm{x}$ axis) (Figure 2). Indeed, we decided to use the ASP with nitrogen removal as a reference in our comparison, as it is nowadays the most common process over Europe since the discharge objectives stated by the European Commission (European Directive 91/271/EEC (1991)) with for instance about $75 \%$ of the current French WWTPs.

Primary treatment sedimentation tank provide $\mathrm{R}$ in the range $0-40 \%$ for the molecules tested (Figure 2A), whereas, $\mathrm{R}$ with biological treatment are mainly in the range 50-90\% (Figure 2B). For most molecules, activated sludge with nitrogen removal (low loaded ASP) is more efficient than activated sludge without nitrogen removal (highly loaded ASP) (Figure 2B). Considering Figure $2 \mathrm{~B}$, most of the $\mathrm{R}$ values obtained with phosphorus activated sludge treatment are comparable to the ones recorded for activated sludge with nitrogen removal. However, for some molecules, $\mathrm{R}$ values appear to be higher or lower. This could be explained by the lack of specification on the type of process: indeed, the type of phosphorus removal (biological or chemical) is never specified in the original papers and the authors may also have omitted to mention an additional nitrogen treatment.

Removal for membrane bioreactor (MBR, which consists of ASP with very high sludge retention time and a filtration stage), fixed biomass reactor and waste stabilization ponds are compared to low loaded ASP in Figure 2C. Values of R for MBR are equivalent to R for low loaded ASP for some molecules (e.g., diclofenac, ibuprofen, sulfamethoxazole, carbamazepin, estrone) ; MBR is more efficient for three molecules (i.e., roxithromycin, tonalide and galaxolide). It is difficult to conclude on the $\mathrm{R}$ values with fixed growth biomass processes because of the too small number of data (only 
6 molecules with both data on low loaded ASP and fixed growth biomass process). Fixed growth biomass process was found very efficient $(\mathrm{R}>92 \%)$ to remove estrone, $17 \alpha$ and $\beta$ estradiol. It also allowed to remove tetracycline and sulfamethoxazole with $\mathrm{R}$ of 58 and $75 \%$ respectively. High values of $\mathrm{R}$ were obtained with waste stabilisation ponds: $\mathrm{R}>87 \%$ for estrone, $17 \alpha$ and $\beta$ estradiol, galaxolide and tonalide. This can be explained by the high hydraulic retention time (HRT) and sludge retention time (SRT) and also by possible photodegradation for this type of process. The two low $\mathrm{R}$ values obtained for fixed biomass reactor and waste stabilization pond in Figure $2 \mathrm{C}$ correspond to $17 \alpha$-ethinylestradiol.

\section{Influence of the influent concentration on $R$ values}

For each type of process, we also tested the influence of influent concentration on R of PPCPs. We examined only the data set (removal vs influent concentration) with more than 10 paired results. We were able to observe a tendency of higher values of $\mathrm{R}$ with higher influent concentration for 5 molecules over 9 with low loaded ASP: 3 hormones (17 $\alpha$ ethinylestradiol, $17 \beta$ estradiol, estriol), diclofenac and ketoprofen. For the 4 other molecules (estrone, ibuprofen, norfloxacin and mefenamic acid), no tendency were shown. We wonder if processes would be less efficient under a minimum influent concentration which would be interesting to determine and to compare with future regulations.

\section{Influence of the operating conditions on $R$ values}

The hydraulic retention time (HRT) and the sludge retention time (SRT) are often used to explain the variation of PPCPs removal efficiency for WWTPs (Henze et al., 1996, Clara et al., 2005). Indeed, high retention times allow low rate reactions like biodegradation and sorption mechanisms to occur.

For several reasons, statistical analyse of the influence of SRT and HRT was difficult to perform using our database. Firstly, HRT and SRT were rarely mentioned in papers from our database on PPCPs in WWTPs. Secondly, most authors did not specify how they calculated HRT. Indeed, HRT could be calculated according to 2 different definitions, taking into account, or not, the flow of the recycling water. This difference of calculation may induce misinterpretations of the HRT influence on R. Thirdly, R can be influenced by various other factors, such as the temperature of the mixed liquor inside the biological reactor $(\mathrm{T})$, the presence of inhibitors (antibiotics or metals), the concentration of the PPCP of interest in the influent, the $\mathrm{pH}$ in the biological reactor, the total suspended solids, the concentration of dissolved oxygen, the agitation condition, the nature of the molecule and the type of process. Fourthly, it is not possible to perform principal component 
analysis and to test the effect of all factors, because our data set for each molecule is not complete. Indeed, a meticulous description of the WWTP process together with all operating factors are far from being presented in all papers dealing with PPCPs in WWTPs. And lastly, when testing one parameter influencing removal, it is necessary that the other ones do not vary, which is not necessarily verified when compiling data from various authors.

To conclude, more specific in situ study with pilot seems to be necessary to rigorously put in light the effect of T, HRT and SRT as it was done for example by Clara et al. (2005).

\section{CONCLUSION AND PERSPECTIVES}

Using our database, we were able to identify the most investigated PPCPs in WWTPs and the most persistent ones in the dissolved phase. We also computed reliable and quantitative values on concentrations, frequency of detection and removals for about 50 molecules. We could compare various WWTP processes for a limited number of molecules and pointed out activated sludge with nitrogen treatment and membrane bioreactor as the most efficient ones.

By further statistical tests compiling data from our database, it was difficult to conclude on the influence of operating conditions, such as T, SRT, HRT, on PPCPs removal. Indeed, a limit of such a database is that it is not possible to perform PCA since the dataset is rarely complete (i.e. lack of information on process or operating conditions for each molecule removal data). Furthermore, it is not possible to test each operating condition independently as in real conditions, they could vary together.

These results do not take into account the full removal of PPCP in WWTPs as only the dissolved concentrations are usually measured and reported in the literature. This probably does not change results dramatically for hydrophilic molecules, but it cannot be overlooked for more hydrophobic compounds, such as hormones for instance.

\section{AKNOWLEDGEMENTS}

This work has been supported by the French National Research Agency (ANR, AMPERES project), the European Commission projects NORMAN and KNAPPE and the French Water Agency Rhône Méditerranée et Corse. 


\section{REFERENCES}

Clara, M., Strenn, B., Gans, O., Martinez, E., Kreuzinger, N., Kroiss, H., 2005. Removal of selected pharmaceuticals, fragrances and endocrine disrupting compounds in a membrane bioreactor and conventional wastewater treatment plants. Water Research 39, 4797-4807.

Daughton, C.G., Ternes, T.A., 1999. Pharmaceuticals and personal care products in the environment: Agents of subtle change? Environmental Health Perspectives 107 Supplement 6, 907-938.

European directive 91/271/EEC (1991), Urban wastewater treatment.

Fent, K., Weston, A.A., Caminada, D., 2006. Ecotoxicology of human pharmaceuticals. Aquat. Toxicol. 76, 122-159.

Garric, J., Ferrari, B., 2005. Pharmaceuticals in aquatic ecosystems. Levels of exposure and biological effects : a review. Rev. Sci. Eau 18/3.

Halling-Sorensen, B., Nielsen, S.N., Lanzky, P.F., Ingerslev, F., Lutzhoft, H.C.H., Jorgensen, S.E., 1998. Occurrence, fate and effects of pharmaceutical substances in the environment - A review. Chemosphere 36, 357-394.

Heberer, T., 2002. Occurrence, fate, and removal of pharmaceutical residues in the aquatic environment: A review of recent research data. Toxicology Letters 131, 5-17.

Henze, M., Harremoës, P., la Cour Jansen, J. and Arvin, A., 1996. Wastewater Treatment. Biological and Chemical processes. Springler-Verlag 383 p.

Hernando, M.D., Fernandez-Alba, A.R., Tauler, R., Barcelo, D., 2005. Toxicity assays applied to wastewater treatment. Talanta 65, 358-366.

Janex-Habibi, M.L., Bruchet, A., Ternes, T.A., 2004. Effet des traitements d'eau potable et d'épuration des eaux usées sur les résidus médicamenteux. Résultats du projet Poseidon. TSM 11.

Jones, A.H., Voulvoulis, N., Lester, J.N., 2004. Potential ecological and human health risks associated with the presence of pharmaceutically active compounds in the aquatic environment. Critical Reviews in Toxicology 34, 335-350.

Jorgensen, S.E., Halling-Sorensen, B., 2000. Drugs in the environment. CHEMOSPHERE 40, 691-699.

Kummerer, K., 2001. Drugs in the environment: Emission of drugs, diagnostic aids and disinfectants into wastewater by hospitals in relation to other sources - A review. Chemosphere 45, 957-969.

Kuster, M., Jose Lopez de Alda, M., Barcelo, D., 2004. Analysis and distribution of estrogens and progestogens in sewage sludge, soils and sediments. TrAC Trends in Analytical Chemistry 23, 790-798.

Larsen, T.A., Lienert, J., Joss, A., Siegrist, H., 2004. How to avoid pharmaceuticals in the aquatic environment. Journal of Biotechnology 113, 295-304.

Petrovic, M., Gonzalez, S., Barcelo, D., 2003. Analysis and removal of emerging contaminants in wastewater and drinking water. Trac-Trends Anal. Chem. 22, 685-696.

Ternes, T.A., Bonerz, M., Schmidt, T., 2001. Determination of neutral pharmaceuticals in wastewater and rivers by liquid chromatography-electrospray tandem mass spectrometry. Journal of Chromatography A 938 (1-2), 175-185.

Zuccato, E., Castiglioni, S., Fanelli, R., Reitano, G., Bagnati, R., Chiabrando, C., Pomati, F., Rossetti, C., Calamari, D. 2006. Pharmaceuticals in the environment in Italy: Causes, occurrence, effects and control. Environmental Science and Pollution Research 13 (1), 15-21

Zwiener, C., Frimmel, F.H., 2004. LC-MS analysis in the aquatic environment and in water treatment technology - a critical review - Part II: Applications for emerging contaminants and related pollutants, microorganisms and humic acids. Analytical and Bioanalytical Chemistry 378, 862-874. 


\section{ANNEX 1 : List of publications used in the database}

Adams, C., Wang, Y., Loftin, K., Meyer, M., 2002. Removal of antibiotics from surface and distilled water in conventional water treatment processes. Journal of Environmental Engineering-Asce 128, 253-260.

Andersen, H., Siegrist, H., Halling-Sorensen, B., Ternes, T.A., 2003. Fate of estrogens in a municipal sewage treatment plant. Environmental Science \& Technology 37, 4021-4026.

Andreozzi, R., Campanella, L., Fraysse, B., Garric, J., Gonnella, A., Lo Giudice, R., Marotta, R., Pinto, G., Pollio, A., 2004. Effects of advanced oxidation processes (AOPs) on the toxicity of a mixture of pharmaceuticals. Water Science and Technology 50, 23-28.

Andreozzi, R., Canterino, M., Lo Giudice, R., Marotta, R., Pinto, G., Pollio, A., 2006. Lincomycin solar photodegradation, algal toxicity and removal from wastewaters by means of ozonation. Water Research 40 , 630-638.

Andreozzi, R., Canterino, M., Marotta, R., Paxeus, N., 2005. Antibiotic removal from wastewaters: The ozonation of amoxicillin. J. Hazard. Mater. 122, 243-250.

Andreozzi, R., Caprio, V., Ciniglia, C., De Champdore, M., Lo Giudice, R., Marotta, R., Zuccato, E., 2004. Antibiotics in the environment: Occurrence in Italian STPs, fate, and preliminary assessment on algal toxicity of amoxicillin. Environmental Science \& Technology 38, 6832-6838.

Andreozzi, R., Caprio, V., Marotta, R., Radovnikovic, A., 2003. Ozonation and H2O2/UV treatment of clofibric acid in water: a kinetic investigation. J. Hazard. Mater. 103, 233-246.

Andreozzi, R., Caprio, V., Marotta, R., Vogna, D., 2003. Paracetamol oxidation from aqueous solutions by means of ozonation and H2O2/UV system. Water Research 37, 993-1004.

Andreozzi, R., Raffaele, M., Nicklas, P., 2003. Pharmaceuticals in STP effluents and their solar photodegradation in aquatic environment. Chemosphere 50, 1319-1330.

Ashton, D., Hilton, M., Thomas, K.V., 2004. Investigating the environmental transport of human pharmaceuticals to streams in the United Kingdom. Science of the Total Environment 333, 167-184.

Baronti, C., Curini, R., D'Ascenzo, G., Di Corcia, A., Gentili, A., Samperi, R., 2000. Monitoring natural and synthetic estrogens at activated sludge sewage treatment plants and in a receiving river water. Environmental Science \& Technology 34, 5059-5066.

Batt, A.L., Kim, S., Aga, D.S., 2006. Enhanced biodegradation of lopromide and trimethoprim in nitrifying activated sludge. Environmental Science and Technology 40(23), 7367-7373

Belfroid, A.C., Van der Horst, A., Vethaak, A.D., Schafer, A.J., Rijs, G.B.J., Wegener, J., Cofino, W.P., 1999. Analysis and occurrence of estrogenic hormones and their glucuronides in surface water and waste water in The Netherlands. Science of the Total Environment 225, 101-108.

Bendz, D., Paxeus, N.A., Ginn, T.R., Loge, F.J., 2005. Occurrence and fate of pharmaceutically active compounds in the environment, a case study: Hoje River in Sweden. J. Hazard. Mater. 122, 195-204.

Boyd, G.R., Reemtsma, H., Grimm, D.A., Mitra, S., 2003. Pharmaceuticals and personal care products (PPCPs) in surface and treated waters of Louisiana, USA and Ontario, Canada. The Science of The Total Environment 311, 135-149.

Braga, O., Smythe, G.A., Schafer, A.I., Feitz, A.J., 2005. Fate of steroid estrogens in Australian inland and coastal wastewater treatment plants. Environmental Science \& Technology 39, 3351-3358.

Braga, O., Smythe, G.A., Schafer, A.I., Feltz, A.J., 2005. Steroid estrogens in primary and tertiary wastewater treatment plants. Water Science and Technology 52, 273-278.

Brown, K.D. (2004) Pharmaceutically active compounds in residential and hospital effluents, municipal wastewater, and the Rio Grande in Albuquerque, New Mexico., University of New Mexico.

Bruchet, A., Castillo, L., Esperanza, M., Janex-Habibi, M.L., Herry, G., Huyard, A., Pasanau, J., 2006. Présence et devenir des perturbateurs endocriniens dans les stations de traitement des eaux résiduaires urbaines.

Buerge, I.J., Buser, H.R., Poiger, T., Müller, M.D., 2006. Occurence and fate of the cytostatic drugs cyclophosphamide and ifosfamide in wastewater and surface waters. Environ. Sci. Technol. 40, 7242-7250.

Buser, H. R., Poiger, T. and Muller, M. D., 1998. Occurrence and fate of the pharmaceutical drug diclofenac in surface waters: Rapid photodegradation in a lake. Environmental Science \& Technology 32(22): 34493456.

Buser, H.R., Poiger, T., Muller, M.D., 1999. Occurrence and environmental behavior of the chiral pharmaceutical drug ibuprofen in surface waters and in wastewater. Environmental Science \& Technology $33,2529-2535$. 
Carballa, M., Omil, F., Lema, J.M., Llompart, M., Garcia-Jares, C., Rodriguez, I., Gomez, M., Ternes, T., 2004. Behavior of pharmaceuticals, cosmetics and hormones in a sewage treatment plant. Water Research 38, 2918-2926.

Carballa, M., Omil, F., Lema, J.M., Llompart, M., Garcia, C., Rodriguez, I., Gomez, M., Ternes, T., 2005. Behavior of pharmaceuticals and personal care products in a sewage treatment plant of northwest Spain. Water Science and Technology 52, 29-35.

Cargouet, M., Perdiz, D., Mouatassim-Souali, A., Tamisier-Karolak, S., Levi, Y., 2004. Assessment of river contamination by estrogenic compounds in Paris area (France). Science of the Total Environment 324, 5566.

Castiglioni, S., Bagnati, R., Fanelli, R., Pomati, F., Calamari, D., Zuccato, E., 2006. Removal of pharmaceuticals in sewage treatment plants in Italy. Environmental Science \& Technology 40, 357-363.

Clara, M., Kreuzinger, N., Strenn, B., Gans, O., Kroiss, H., 2005. The solids retention time - a suitable design parameter to evaluate the capacity of wastewater treatment plants to remove micropollutants. Water Research 39, 97-106.

Clara, M., Strenn, B., Ausserleitner, M., Kreuzinger, N., 2004. Comparison of the behaviour of selected micropollutants in a membrane bioreactor and a conventional wastewater treatment plant. Water Science and Technology 50, 29-36.

Clara, M., Strenn, B., Gans, O., Martinez, E., Kreuzinger, N., Kroiss, H., 2005. Removal of selected pharmaceuticals, fragrances and endocrine disrupting compounds in a membrane bioreactor and conventional wastewater treatment plants. Water Research 39, 4797-4807.

Clara, M., Strenn, B., Kreuzinger, N., 2004. Carbamazepine as a possible anthropogenic marker in the aquatic environment: investigations on the behaviour of Carbamazepine in wastewater treatment and during groundwater infiltration. Water Research 38, 947-954.

Dagnac, T., Bristeau, S., Coton, C., Leroy, C., Fleury, N., Jeannot, R., 2005. Analyse de polluants organiques et organométalliques dans l'environnement.

Desbrow, C., Routledge, E.J., Brighty, G.C., Sumpter, J.P., Waldock, M., 1998. Identification of estrogenic chemicals in STW effluent. 1. Chemical fractionation and in vitro biological screening. Environmental Science \& Technology 32, 1549-1558.

Drewes, J.E., Heberer, T., Reddersen, K., 2002. Fate of pharmaceuticals during indirect potable reuse. Water Science and Technology 46, 73-80.

Drewes, J.E., Hemming, J., Ladenburger, S., Schauer, J., Sonzogni, W., 2005. Endocrine disrupting activity changes in water reclamation systems. Water environment federation.

Drewes, J.E., Hemming, J., Ladenburger, S.J., Schauer, J., Sonzogni, W., 2005. An assessment of endocrine disrupting activity changes during wastewater treatment through the use of bioassays and chemical measurements. Wat. Environ. Res. 77, 12-23.

Esperanza, M., Suidan, M.T., Marfil-Vega, R., Gonzalez, C., Sorial, G.A., McCauley, P., Brenner, R., 2007. Fate of sex hormones in two pilot-scale municipal wastewater treatment plants: Conventional treatment. Chemosphere 66, 1535-1544.

Esperanza, M., Suidan, M.T., Nishimura, F., Wang, Z.M., Sorial, G.A., 2004. Determination of sex hormones and nonylphenol ethoxylates in the aqueous matrixes of two pilot-scale municipal wastewater treatment plants. Environmental Science \& Technology 38, 3028-3035.

Esperanza M., Suidan M. T., Vega R. M., Gonzalez C., Sorial G. A., Paul McCauley, P., Brenner R., 2007. Fate of sex hormones in two pilot-scale municipal wastewater treatment plants: Conventional treatment. Chemosphere. 66: 1535-1544.

Farre, M., Ferrer, I., Ginebreda, A., Figueras, M., Olivella, L., Tirapu, L., Vilanova, M., Barcelo, D., 2001. Determination of drugs in surface water and wastewater samples by liquid chromatography-mass spectrometry: methods and preliminary results including toxicity studies with Vibrio fischeri. Journal of Chromatography A 938, 187-197.

Gobel, A., Thomsen, A., McArdell, C.S., Joss, A., Giger, W., 2005. Occurrence and sorption behavior of sulfonamides, macrolides, and trimethoprim in activated sludge treatment. Environmental Science \& Technology 39, 3981-3989.

Golet, E.M., Alder, A.C., Hartmann, A., Temes, T.A., Giger, W., 2001. Trace determination of fluoroquinolone antibacterial agents in urban wastewater by solid-phase extraction and liquid chromatography with fluorescence detection. Analytical Chemistry 73, 3632-3638.

Golet, E.M., Xifra, I., Siegrist, H., Alder, A.C., Giger, W., 2003. Environmental exposure assessment of fluoroquinolone antibacterial agents from sewage to soil. Environmental Science \& Technology 37, 32433249. 
Gross, B., Montgomery-Brown, J., Naumann, A., Reinhard, M., 2004. Occurrence and fate of pharmaceuticals and alkylphenol ethoxylate metabolites in an effluent-dominated river and wetland. Environmental Toxicology and Chemistry 23, 2074-2083.

Han, G.H., Hur, H.G., Kim, S.D., 2006. Ecotoxicological risk of pharmaceuticals from wastewater treatment plants in Korea: Occurrence and toxicity to Daphnia magna. Environmental Toxicology and Chemistry 25, 265-271.

Hannich, C.B., Ries, T., Fahlenkamp, H., 2005. Occurrence and elimination of organic compounds in municipal wastewater treatment plants.

Heberer, T., 2002. Tracking persistent pharmaceutical residues from municipal sewage to drinking water. Journal of Hydrology 266, 175-189.

Heberer, T., Feldmann, D., Reddersen, K., Altmann, H.J., Zimmermann, T., 2001. Removal of pharmaceutical residues and other persistent organics from municipal sewage and surface waters applying membrane filtration. 18-29.

Heidler, J. and Halden, R. U., 2007. Mass balance assessment of triclosan removal during conventional sewage treatment. Chemosphere 66(2): 362-369.

Herry-Leroy, G., Raulet, C., Beausse, J., 2006. Study of new emerging pollutants in the environment : Endocrine disrupters - analysis of steroid hormones in waste water treatment plants using LC/MS-MS. European journal of water quality 37, 39-52.

Hirsch, R., Ternes, T., Haberer, K., Kratz, K.-L., 1999. Occurrence of antibiotics in the aquatic environment. Science of the Total Environment 225, 109-118.

Hua, J.M., An, P.L., Winter, J., Gallert, C., 2003. Elimination of COD, microorganisms and pharmaceuticals from sewage by trickling through sandy soil below leaking sewers. Water Research 37, 4395-4404.

Huber, M.M., Canonica, S., Park, G.Y., Von Gunten, U., 2003. Oxidation of pharmaceuticals during ozonation and advanced oxidation processes. Environmental Science \& Technology 37, 1016-1024.

Huber, M.M., Gobel, A., Joss, A., Hermann, N., Loffler, D., McArdell, C.S., Ried, A., Siegrist, H., Ternes, T.A., von Gunten, U., 2005. Oxidation of pharmaceuticals during ozonation of municipal wastewater effluents: A pilot study. Environmental Science \& Technology 39, 4290-4299.

Huber, M.M., Korhonen, S., Ternes, T.A., von Gunten, U., 2005. Oxidation of pharmaceuticals during water treatment with chlorine dioxide. Water Research 39, 3607-3617.

Huggett, D.B., Khan, I.A., Foran, C.M., Schlenk, D., 2003. Determination of beta-adrenergic receptor blocking pharmaceuticals in united states wastewater effluent. Environmental Pollution 121, 199-205.

Johnson, A.C., Aerni, H.R., Gerritsen, A., Gibert, M., Giger, W., Hylland, K., Jurgens, M., Nakari, T., Pickering, A., Suter, M.J.F., Svenson, A., Wettstein, F.E., 2005. Comparing steroid estrogen, and nonylphenol content across a range of European sewage plants with different treatment and management practices. Water Research 39, 47-58.

Johnson, A.C., Belfroid, A., Di Corcia, A., 2000. Estimating steroid oestrogen inputs into activated sludge treatment works and observations on their removal from the effluent. Science of the Total Environment 256, 163-173.

Joss, A., Andersen, H., Ternes, T., Richle, P.R., Siegrist, H., 2004. Removal of estrogens in municipal wastewater treatment under aerobic and anaerobic conditions: Consequences for plant optimization. Environmental Science \& Technology 38, 3047-3055.

Kanda, R., Griffin, P., James, H.A., Fothergill, J., 2003. Pharmaceutical and personal care products in sewage treatment works. Journal of Environmental Monitoring 5, 823-830.

Karthikeyan, K.G., Meyer, M.T., 2006. Occurrence of antibiotics in wastewater treatment facilities in Wisconsin, USA. Science of the Total Environment 361 (1-3), 196-207.

Khan, S.J., Ongerth, J.E., 2002. Estimation of pharmaceutical residues in primary and secondary sewage sludge based on quantities of use and fugacity modelling. Water Science and Technology 46, 105-113.

Kimura, K., Amy, G., Drewes, J.E., Heberer, T., Kim, T.U., Watanabe, Y., 2003. Rejection of organic micropollutants (disinfection by-products, endocrine disrupting compounds, and pharmaceutically active compounds) by NF/RO membranes. Journal of Membrane Science 227, 113-121.

Kimura, K., Hara, H., Watanabe, Y., 2005. Removal of pharmaceutical compounds by submerged membrane bioreactors (MBRs). Desalination 178, 135-140.

Kimura, K., Toshima, S., Amy, G., Watanabe, Y., 2004. Rejection of neutral endocrine disrupting compounds (EDCs) and pharmaceutical active compounds (PhACs) by RO membranes. Journal of Membrane Science 245, 71-78.

Komori, K., Tanaka, H., Okayasu, Y., Yasojima, M., Sato, C., 2004. Analysis and occurrence of estrogen in wastewater in Japan. Water Science and Technology 50, 93-100. 
Koutsouba, V., Heberer, T., Fuhrmann, B., Schmidt-Baumler, K., Tsipi, D., Hiskia, A., 2003. Determination of polar pharmaceuticals in sewage water of Greece by gas chromatography-mass spectrometry. Chemosphere 51, 69-75.

Kuch, H.M., Ballschmiter, K., 2000. Determination of endogenous and exogenous estrogens in effluents from sewage treatment plants at the ng/L-level. Fresenius Journal of Analytical Chemistry 366, 392-395.

Kummerer, K., StegerHartmann, T., Meyer, M., 1997. Biodegradability of the anti-tumour agent ifosfamide and its occurrence in hospital effluents and communal sewage. Water Research 31, 2705-2710.

Labadie, P., Budzinski, H., 2005. Determination of steroidal hormone profiles along the Jalle d'Eysines River (near Bordeaux, France). Environmental Science \& Technology 39, 5113-5120.

Labadie, P., Budzinski, H., 2005. Development of an analytical procedure for determination of selected estrogens and progestagens in water samples. Anal. Bioanal. Chem. 381, 1199-1205.

Layton, A.C., Gregory, B.W., Seward, J.R., Schultz, T.W., Sayler, G.S., 2000. Mineralization of steroidal hormones by biosolids in wastewater treatment systems in Tennessee USA. Environmental Science \& Technology 34, 3925-3931.

Lindqvist, N., Tuhkanen, T., Kronberg, L., 2005. Occurrence of acidic pharmaceuticals in raw and treated sewages and in receiving waters. Water Research 39, 2219-2228.

Lishman, L., Smyth, S.A., Sarafin, K., Kleywegt, S., Toito, J., Peart, T., Lee, B., Servos, M., Beland, M., Seto, P., 2006. Occurence and reductions of pharmaceuticals and personal care products and estrogens by municipal wastewater treatment plants in Ontario, Canada. Science of the Total Environment 367, 544.

Loraine, G.A., Pettigrove, M.E., 2006. Seasonal variations in concentrations of pharmaceuticals and personal care products in drinking water and reclaimed wastewater in Southern California. Environmental Science \& Technology 40, 687-695.

Matamoros, V., Garcia, J., Bayona, J.M., 2005. Behavior of selected pharmaceuticals in subsurface flow constructed wetlands: A pilot-scale study. Environmental Science \& Technology 39, 5449-5454.

McArdell, C.S., Molnar, E., Suter, M.J.F., Giger, W., 2003. Occurrence and fate of macrolide antibiotics in wastewater treatment plants and in the Glatt Valley Watershed, Switzerland. Environmental Science \& Technology 37, 5479-5486.

Metcalfe, C.D., Koenig, B.G., Bennie, D.T., Servos, M., Ternes, T.A., Hirsch, R., 2003. Occurrence of neutral and acidic drugs in the effluents of canadian sewage treatment plants. Environmental Toxicology and Chemistry 22, 2872-2880.

Metcalfe, C.D., Miao, X.S., Koenig, B.G., Struger, J., 2003. Distribution of acidic and neutral drugs in surface waters near sewage treatment plants in the lower Great Lakes, Canada. Environmental Toxicology and Chemistry 22, 2881-2889.

Miao, X.S., Yang, J.J., Metcalfe, C.D., 2005. Carbamazepine and its metabolites in wastewater and in biosolids in a municipal wastewater treatment plant. Environmental Science \& Technology 39, 7469-7475.

Miège, C., Favier, M., Brosse, C., Canler, J., Coquery, M., 2006. Occurence of betablockers in effluents of wastewater treatment plants from the Lyon area (France) and risk assessment for the downstream rivers. Talanta 70, 739-744.

Mouatassim-Souali, A., Tamisier-Karolak, S., Perdiz, D., Cargouet, M., Levi, Y., 2003. Validation of a quantitative assay using GC/MS for trace determination of free and conjugated estrogens in environmental water samples. J. Sep. Sci. 26, 105-111.

Nasu, M., Goto, M., Kato, H., Oshima, Y., Tanaka, H., 2001. Study on endocrine disrupting chemicals in wastewater treatment plants. Water Science and Technology 43, 101-108.

Ollers, S., Singer, H.P., Fassler, P., Muller, S.R., 2001. Simultaneous quantification of neutral and acidic pharmaceuticals and pesticides at the low-ng/1 level in surface and waste water. Journal of Chromatography A 911, 225-234.

Paffoni, C., Welte, B., Gousailles, M., Montiel, A., 2006. New molecules involved by the european directives : from wastewater to drinking water treatment plants. European journal of water quality 37, 21-38.

Paxeus, N., 2004. Removal of selected non-steroidal anti-inflammatory drugs (NSAIDs), gemfibrozil, carbamazepine, -blockers, trimethoprim and triclosan in conventional wastewater treatment plants in five EU countries and their discharge to the aquatic environment. Water Science and Technology 50, 253-260.

Petrovic, M., Sole, M., de Alda, M.J.L., Barcelo, D., 2002. Endocrine disruptors in sewage treatment plants, receiving river waters, and sediments: Integration of chemical analysis and biological effects on feral carp. Environmental Toxicology and Chemistry 21, 2146-2156.

Rabiet, M., Togola, A., Brissaud, F., Seidel, J.-L., Budzinski, H., Elbaz-poulichet, F., 2006. Consequences of treated water recycling as regards pharmaceuticals and drugs in surface and ground waters of a mediumsized mediterranean catchment. Environmental Science \& Technology 40, 5282-5288. 
Reinhard, M., Gross, B., Hadeler, A., 2003. Emerging contaminants in tertiary treated wastewater. Chimia 57, 31-32.

Roberts, P. H. and Thomas, K. V., 2005. "The occurrence of selected pharmaceuticals in wastewater effluents and surface waters of the lower Tyne catchment." Science of the Total Environment 356: 143-153.

Rodriguez, I., Quintana, J.B., Carpinteiro, J., Carro, A.M., Lorenzo, R.A., Cela, R., 2003. Determination of acidic drugs in sewage water by gas chromatography-mass spectrometry as tert.-butyldimethylsilyl derivatives. Journal of Chromatography A 985, 265-274.

Santos, J.L., Aparicio, I., Alonso, E., Callejon, M., 2005. Simultaneous determination of pharmaceutically active compounds in wastewater samples by solid phase extraction and high-performance liquid chromatography with diode array and fluorescence detectors. Analytica Chimica Acta 550, 116-122.

Sedlak, D.L., Pinkston, K.E., 2001. Factors affecting the concentrations of pharmaceuticals released to the aquatic environment. Water resources Update, 56-64.

Servos, M.R., Bennie, D.T., Burnison, B.K., Jurkovic, A., McInnis, R., Neheli, T., Schnell, A., Seto, P., Smyth, S.A., Ternes, T.A., 2005. Distribution of estrogens, 17 beta-estradiol and estrone, in Canadian municipal wastewater treatment plants. Science of the Total Environment 336, 155-170.

Soulet, B., Tauxe, A., Tarradellas, J., 2002. Analysis of acidic drugs in Swiss wastewaters. International Journal of Environmental Analytical Chemistry 82, 659-667.

Strenn, B., Clara, M., Gans, O., Kreuzinger, N., 2004. Carbamazepine, diclofenac, ibuprofen and bezafibrate - investigations on the behaviour of selected pharmaceuticals during wastewater treatment. Water Science and Technology 50, 269-276.

Stumpf, M., Ternes, T.A., Wilken, R.-D., Silvana Vianna Rodrigues, Baumann, W., 1999. Polar drug residues in sewage and natural waters in the state of Rio de Janeiro, Brazil. The Science of The Total Environment 225, 135-141.

Suarez, S., Ramill, M., Omil, F., Lema, J.M., 2005. Removal of pharmaceutically active compounds in nitrifying-denitrifying plants. Water Science and Technology 52, 9-14.

Tauxe-Wuersch, A., De Alencastro, L.F., Grandjean, D., Tarradellas, J., 2005. Occurrence of several acidic drugs in sewage treatment plants in Switzerland and risk assessment. Water Research 39, 1761-1772.

Tauxe-Wuersch, A., de Alencastro, L.F., Grandjean, D., Tarradellas, J., 2006. Trace determination of tamoxifen and 5-fluorouracil in hospital and urban wastewaters. International Journal of Environmental Analytical Chemistry 86, 473-485.

Ternes, T.A., 1998. Occurrence of drugs in German sewage treatment plants and rivers. Water Research 32, 3245-3260.

Ternes, T.A., Bonerz, M., Schmidt, T., 2001. Determination of neutral pharmaceuticals in wastewater and rivers by liquid chromatography-electrospray tandem mass spectrometry. Journal of Chromatography A 938 (1-2), 175-185.

Ternes, T.A., Hirsch, R., 2000. Occurrence and behavior of X-ray contrast media in sewage facilities and the aquatic environment. Environmental Science and Technology 34, 2741-2748.

Ternes, T.A., Meisenheimer, M., McDowell, D., Sacher, F., Brauch, H.-J., Haist-Gulde, B., Preuss, G., Wilme, U., Zulei-Seibert, N., 2002. Removal of pharmaceuticals during drinking water treatment. Environmental Science and Technology 36, 3855-3863.

Ternes, T.A., Stuber, J., Herrmann, N., McDowell, D., Ried, A., Kampmann, M., Teiser, B., 2003. Ozonation: A tool for removal of pharmaceuticals, contrast media and musk fragrances from wastewater? Water Research 37, 1976-1982.

Ternes, T.A., Stumpf, M., Mueller, J., Haberer, K., Wilken, R.-D., Servos, M., 1999. Behavior and occurrence of estrogens in municipal sewage treatment plants - I. Investigations in Germany, Canada and Brazil. Science of the Total Environment 225, 81-90.

Ternes, T.A., Stumpf, M., Schuppert, B., Haberer, K., 1998. Simultaneous determination of antiseptics and acidic drugs in sewage and river water. Vom Wasser 90, 295-309.

Tixier, C., Singer, H.P., Oellers, S., Muller, S.R., 2003. Occurrence and fate of carbamazepine, clofibric acid, diclofenac, ibuprofen, ketoprofen, and naproxen in surface waters. Environmental Science \& Technology 37, 1061-1068.

Urase, T., Kagawa, C., Kikuta, T., 2005. Factors affecting removal of pharmaceutical substances and estrogens in membrane separation bioreactors. Desalination 178, 107-113.

Vader, J. S., van Ginkel, C. G., Sperling, F., de Jong, J., de Boer, W., de Graaf, J. S., van der Most, M. and Stokman, P. G. W., 2000. Degradation of ethinyl estradiol by nitrifying activated sludge. Chemosphere 41(8): 1239-1243. 
Vieno, N.M., Tuhkanen, T., Kronberg, L., 2005. Seasonal variation in the occurrence of pharmaceuticals in effluents from a sewage treatment plant and in the recipient water. Environmental Science \& Technology 39, 8220-8226.

Weber, S., Gallenkemper, M., Melin, T., Dott, W., Hollender, J., 2004. Efficiency of nanofiltration for the elimination of steroids from water. Water Science and Technology 50, 9-14.

Weigel, S., Berger, U., Jensen, E., Kallenborn, R., Thoresen, H., Huhnerfuss, H., 2004. Determination of selected pharmaceuticals and caffeine in sewage and seawater from Tromso/Norway with emphasis on ibuprofen and its metabolites. Chemosphere 56, 583-592.

Westerhoff, P., Yoon, Y., Snyder, S., Wert, E., 2005. Fate of endocrine-disruptor, pharmaceutical, and personal care product chemicals during simulated drinking water treatment processes. Environmental Science \& Technology 39, 6649-6663.

Yang, S., Carlson, K., 2004. Routine monitoring of antibiotics in water and wastewater with a radioimmunoassay technique. Water Research 38, 3155-3166.

Yasojima, M., Nakada, N., Komori, K., Suzuki, Y., Tanaka, H., 2006. Occurence of levofloxacin, clarithromycin and azithromycin in wastewater treatment plant in Japan. Water Science and Technology 53, 227-233.

Zuehlke, S., Duennbier, U., Heberer, T., 2004. Determination of polar drug residues in sewage and surface water applying liquid chromatography-tandem mass spectrometry. Analytical Chemistry 76, 6548-6554.

Zwiener, C., Glauner, T., Frimmel, F.H., 2000. Biodegradation of pharmaceutical residues investigated by SPE-GC/ITD-MS and on-line derivatization. HRC-J. High Resolut. Chromatogr. 23, 474-478.

Zwiener, C., Seeger, S., Glauner, T., Frimmel, F.H., 2002. Metabolites from the biodegradation of pharmaceutical residues of ibuprofen in biofilm reactors and batch experiments. Analytical and Bioanalytical Chemistry 372, 569-575. 
Table 1: The pharmaceuticals and personal care products the most investigated in wastewater treatment plants.

\begin{tabular}{lll}
\hline Therapeutic class & Molecules & Frequency (\%) \\
\hline Hormone & Estrone, 17 $\beta$-estradiol, 17 $\alpha$-ethinylestradiol, Estriol, & 30 \\
& $17 \alpha$-estradiol, Testosterone, Progesterone & \\
Analgesic-antiinflammatory & Ibuprofen, Diclofenac, Naproxen, Ketoprofen, & 20 \\
& Mefenamic acid & \\
Antibiotic & Sulfamethoxazole, Trimetoprim, Ciprofloxacin, & 8.7 \\
& Roxithromycin, Norfloxacin, Clarithromycin, & \\
& Erythromycin & \\
Lipid regulator & Bezafibrate, Gemfibrozil & 4.4 \\
Anti-epileptic & Carbamazepin & 4.0 \\
Metabolite & Clofibric acid, Salicylic acid & 3.9 \\
Betablocker & Metoprolol, Propranolol, Atenolol & 2.8 \\
Personal care product & Galaxolide, Tonalide & 2.7 \\
Contrast product & Iopromide & 1.1 \\
Disinfectant & Triclosan & 0.8 \\
Vasodilator & Pentoxifyllin & 0.7 \\
Antidepressant & Diazepam & 0.6 \\
\hline Total & & $\mathbf{8 0}$ \\
\hline
\end{tabular}

a: frequency of citation in our database (117 papers, 6641 data, 184 molecules) 
Table 2: Mean, minimum and maximum concentrations of pharmaceuticals and personal care products in wastewater treatment plants with activated sludge processes (reported only for individual and mean value with a data set $\mathrm{n} \geq 3$ for influent or effluent). / : no individual value reported

\begin{tabular}{|c|c|c|c|c|c|c|c|c|c|c|c|c|c|c|c|}
\hline \multirow{2}{*}{ Therapeutic class } & \multirow[b]{2}{*}{ Name } & \multicolumn{6}{|c|}{ Concentration in influent $(\mu \mathrm{g} / \mathrm{L})$} & \multirow{2}{*}{$\begin{array}{l}\text { Frequency of } \\
\text { quantification in } \\
\text { influent (\%) }\end{array}$} & \multicolumn{6}{|c|}{ Concentration in effluent $(\mu \mathrm{g} / \mathrm{L})$} & \multirow{2}{*}{$\begin{array}{l}\text { Frequency of } \\
\text { quantification } \\
\text { in effluent (\%) }\end{array}$} \\
\hline & & Mean & $\begin{array}{l}\text { RSD } \\
(\%)\end{array}$ & Median & Min & $\operatorname{Max}$ & $\mathbf{n}$ & & Mean & $\begin{array}{l}\text { RSD } \\
(\%)\end{array}$ & Median & Min & $\operatorname{Max}$ & $\mathbf{n}$ & \\
\hline \multirow{2}{*}{\multicolumn{2}{|c|}{$\begin{array}{l}\text { Analgesic-antiinflammatory Dextropropoxyphene } \\
\text { Analgesic-antiinflammatory Diclofenac }\end{array}$}} & 0.0273 & 20 & 0.0270 & 0.0220 & 0.0330 & 3 & 100 & 0.0523 & 27 & 0.0560 & 0.0370 & 0.0640 & 3 & 100 \\
\hline & & 1.34 & 83 & 0.997 & 0.105 & 4.11 & 91 & 81 & 0.680 & 82 & 0.420 & 0.0350 & 1.95 & 101 & 85 \\
\hline \multicolumn{2}{|c|}{ Analgesic-antiinflammatory Ibuprofen } & 14.6 & 149 & 3.20 & 0.170 & 83.5 & 101 & 97 & 1.96 & 177 & 0.800 & 0.0020 & 24.6 & 109 & 93 \\
\hline \multicolumn{2}{|c|}{ Analgesic-antiinflammatory Ketoprofen } & 1.03 & 117 & 0.340 & 0.0800 & 5.70 & 55 & 73 & 0.325 & 101 & 0.210 & 0.0400 & 1.62 & 53 & 73 \\
\hline \multicolumn{2}{|c|}{ Analgesic-antiinflammatory Mefenamic acid } & 1.73 & 52 & 1.70 & 0.136 & 3.20 & 41 & 100 & 1.14 & 57 & 1.00 & 0.0900 & 2.40 & 41 & 100 \\
\hline \multicolumn{2}{|c|}{ Analgesic-antiinflammatory Naproxen } & 26.4 & 343 & 6.00 & 1.79 & 611 & 45 & 96 & 1.89 & 245 & 0.880 & 0.170 & 33.9 & 53 & 87 \\
\hline \multicolumn{2}{|c|}{ Analgesic-antiinflammatory Paracetamol } & 80.0 & 152 & 26.0 & 5.53 & 292 & 5 & 100 & 1 & I & l & 1 & 1 & 1 & 1 \\
\hline Antibiotic & Azithromycin & 0.260 & & & & & 6 & 100 & 0.138 & & & & & 6 & 100 \\
\hline Antibiotic & Ciprofloxacin & 0.413 & 27 & 0.430 & 0.180 & 0.571 & 20 & 83 & 0.0723 & 27 & 0.071 & 0.0450 & 0.140 & 29 & 91 \\
\hline Antibiotic & Clarithromycin & 0.647 & & & & & 6 & 100 & 0.359 & & & & & 6 & 100 \\
\hline Antibiotic & Erythromycin & 0.108 & 33 & 0.113 & 0.0710 & 0.141 & 3 & 100 & 0.212 & 34 & 0.202 & 0.145 & 0.290 & 3 & 100 \\
\hline Antibiotic & Levofloxacin & 0.552 & & & & & 6 & 100 & 0.301 & & & & & 6 & 100 \\
\hline Antibiotic & Norfloxacin & 0.438 & 12 & 0.433 & 0.343 & 0.515 & 18 & 100 & 0.0608 & 37 & 0.0515 & 0.0390 & 0.120 & 26 & 100 \\
\hline Antibiotic & Roxithromycin & 0.0620 & 62 & 0.0640 & 0.0250 & 0.117 & 5 & 100 & 0.0496 & 27 & 0.0450 & 0.0360 & 0.069 & 5 & 100 \\
\hline Antibiotic & Sulfamethazin & 0.333 & 91 & 0.210 & 0.110 & 0.680 & 3 & 43 & 1 & 1 & / & / & 1 & 1 & 1 \\
\hline Antibiotic & Sulfamethoxazole & 0.342 & 114 & 0.157 & 0.0200 & 1.25 & 10 & 71 & 0.115 & 85 & 0.0700 & 0.0180 & 0.320 & 11 & 73 \\
\hline Antibiotic & Tetracyclin & 0.457 & 43 & 0.465 & 0.240 & 0.790 & 6 & 86 & 0.282 & 135 & 0.115 & 0.0500 & 0.850 & 4 & 67 \\
\hline Antibiotic & Trimetoprim & 0.449 & 94 & 0.281 & 0.0800 & 1.30 & 10 & 100 & 0.118 & 120 & 0.0600 & 0.0200 & 0.550 & 27 & 93 \\
\hline Anti-epileptic & Carbamazepin & 0.968 & 61 & 0.732 & 0.100 & 1.90 & 64 & 100 & 0.674 & 68 & 0.520 & 0.150 & 2.30 & 63 & 100 \\
\hline Antifongic & Clotrimazole & 0.0290 & 18 & 0.0310 & 0.0230 & 0.0330 & 3 & 100 & 0.0170 & 52 & 0.0140 & 0.0100 & 0.0270 & 3 & 100 \\
\hline Antineoplasic, cytostatic & Tamoxifen & 0.170 & 23 & 0.153 & 0.143 & 0.215 & 3 & 19 & 0.238 & 49 & 0.199 & 0.146 & 0.369 & 3 & 19 \\
\hline Betablocker & Atenolol & 0.0300 & & & & & 1 & 100 & 0.154 & 44 & 0.150 & 0.0100 & 0.380 & 18 & 100 \\
\hline Betablocker & Bisoprolol & I & l & 1 & I & l & i & i & 0.709 & 68 & 0.637 & 0.303 & 1.43 & 18 & 100 \\
\hline Betablocker & Metoprolol & 0.160 & & & & & 1 & 100 & 0.338 & 55 & 0.373 & 0.0100 & 0.688 & 37 & 97 \\
\hline Betablocker & Propranolol & 0.0747 & 41 & 0.0650 & 0.0500 & 0.119 & 4 & 100 & 0.341 & 54 & 0.381 & 0.0100 & 0.615 & 24 & 100 \\
\hline Contrast product & lopromide & 4.49 & 75 & 5.22 & 0.0260 & 7.50 & 4 & 57 & 5.68 & 71 & 6.58 & 0.250 & 9.30 & 4 & 57 \\
\hline Disinfectant & Triclosan & 0.380 & & & & & 1 & 100 & 0.150 & 48 & 0.130 & 0.0700 & 0.430 & 19 & 100 \\
\hline Hormone & 17?-estradiol & 0.0074 & 58 & 0.0063 & 0.0015 & 0.0172 & 36 & 100 & 0.0008 & 110 & 0.0006 & 0.0001 & 0.0031 & 9 & 64 \\
\hline Hormone & 17?-ethinylestradiol & 0.0042 & 237 & 0.0019 & 0.0004 & 0.0700 & 70 & 91 & 0.0009 & 120 & 0.0005 & 0.0002 & 0.0050 & 33 & 59 \\
\hline Hormone & 17?-estradiol & 0.0222 & 78 & 0.0186 & 0.0025 & 0.125 & 108 & 100 & 0.0028 & 165 & 0.0015 & 0.0003 & 0.0300 & 63 & 74 \\
\hline Hormone & Estriol & 0.115 & 112 & 0.0695 & 0.0146 & 0.660 & 36 & 100 & 0.0131 & 365 & 0.0014 & 0.0004 & 0.275 & 33 & 92 \\
\hline Hormone & Estrone & 0.0672 & 95 & 0.0600 & 0.0024 & 0.670 & 109 & 100 & 0.0209 & 121 & 0.0100 & 0.0006 & 0.0950 & 79 & 93 \\
\hline Lipid regulator & Bezafibrate & 2.44 & 93 & 2.00 & 0.100 & 7.60 & 25 & 100 & 0.816 & 168 & 0.250 & 0.0200 & 4.80 & 21 & 78 \\
\hline Lipid regulator & Gemfibrozil & 1.63 & 69 & 1.40 & 0.700 & 3.00 & 4 & 25 & 0.564 & 59 & 0.600 & 0.0600 & 1.34 & 21 & 70 \\
\hline Metabolite & Carbamazepin- $10 \mathrm{OH}$ & 0.0222 & & & & & 3 & 100 & 0.0325 & & & & & 3 & 100 \\
\hline Metabolite & Carbamazepin-2OH & 0.0590 & & & & & 3 & 100 & 0.0704 & & & & & 3 & 100 \\
\hline Metabolite & Carbamazepin-3OH & 0.0554 & & & & & 3 & 100 & 0.0692 & & & & & 3 & 100 \\
\hline Metabolite & Carbamazepin-DiOH & 1.001 & & & & & 3 & 100 & 1.08 & & & & & 3 & 100 \\
\hline Metabolite & Carbamazepin-EP & 0.0392 & & & & & 3 & 100 & 0.0191 & & & & & 3 & 100 \\
\hline Metabolite & Clofibric acid & 0.294 & 55 & 0.250 & 0.0150 & 0.651 & 40 & 70 & 0.150 & 46 & 0.152 & 0.0420 & 0.230 & 24 & 55 \\
\hline Metabolite & Erythromycin-H2O & 0.545 & 87 & 0.455 & 0.0700 & 1.20 & 4 & 67 & 0.220 & 52 & 0.270 & 0.0900 & 0.300 & 3 & 50 \\
\hline Metabolite & Salicylic acid & 212 & 81 & 170 & 16.0 & 606 & 16 & 100 & 2.50 & 86 & 2.80 & 0.300 & 4.80 & 5 & 45 \\
\hline Personal care product & Galaxolide & 2.51 & 51 & 3.06 & 0.790 & 4.443 & 9 & 100 & 0.642 & 32 & 0.600 & 0.451 & 1.08 & 9 & 100 \\
\hline Personal care product & Tonalide & 0.990 & 50 & 1.02 & 0.210 & 1.69 & 8 & 100 & 0.162 & 11 & 0.160 & 0.144 & 0.200 & 8 & 100 \\
\hline Vasodilator & Pentoxifyllin & 1 & 1 & 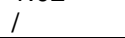 & 1 & 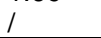 & 1 & 1 & 0.533 & 11 & 0.500 & 0.500 & 0.600 & 3 & 30 \\
\hline
\end{tabular}




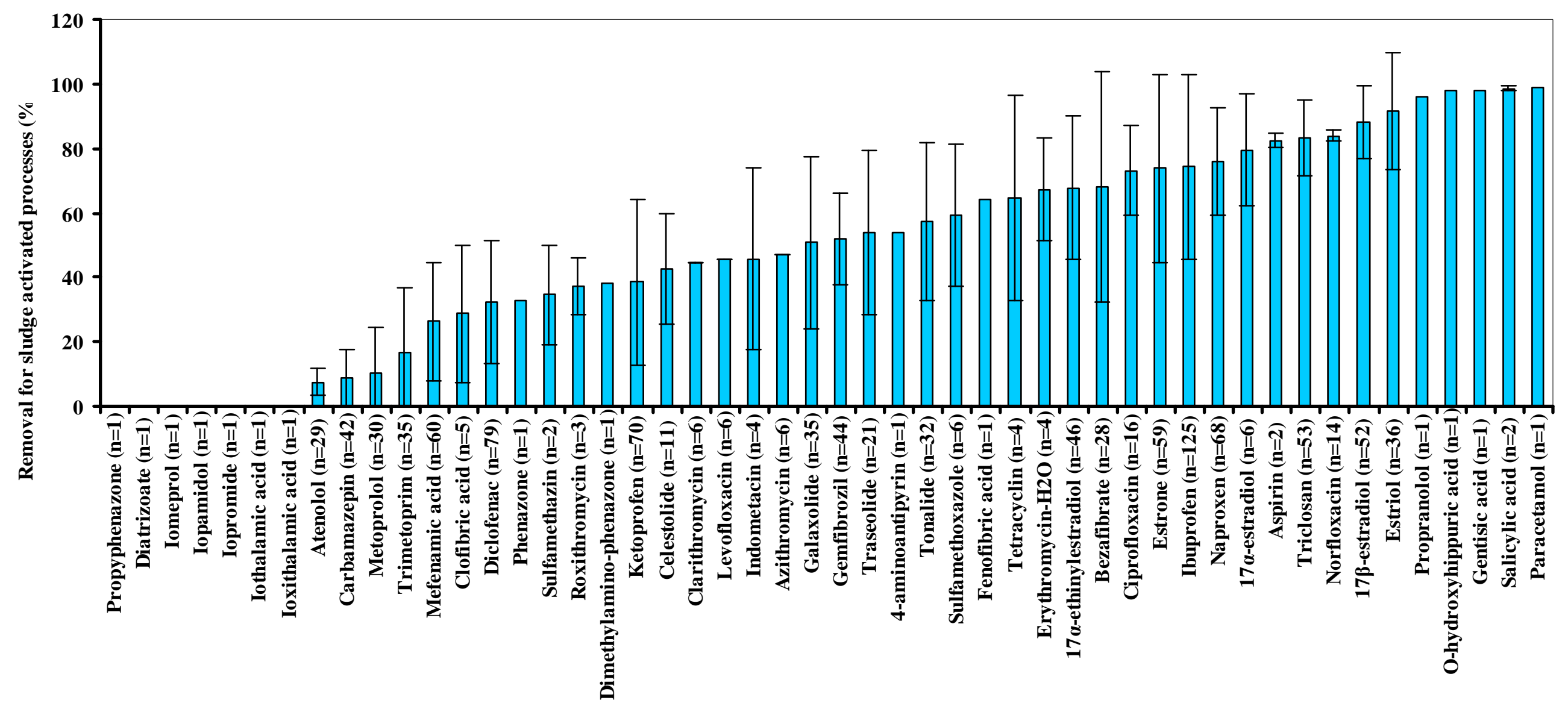

Figure 1: Mean removal efficiency $(\%)$ and relative standard deviation for pharmaceuticals and personal care products in wastewater treatment plants with activated sludge processes. 


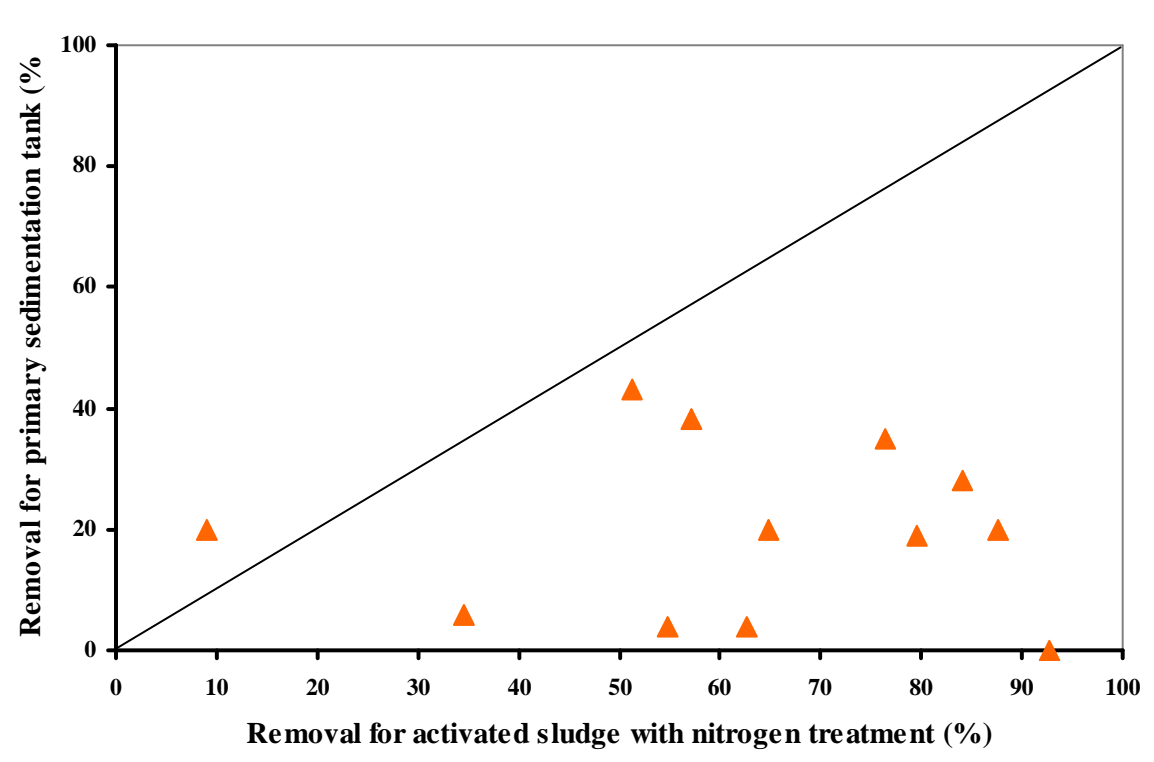

A/

Primary sedimentation tank

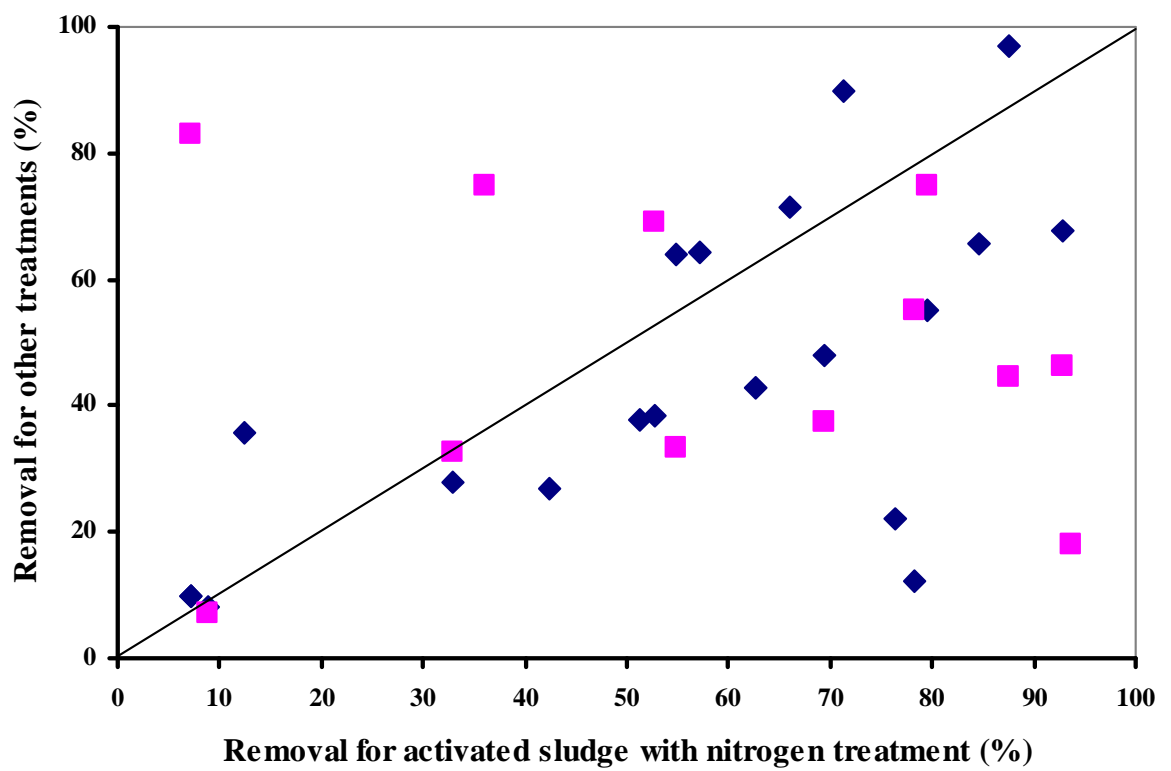

B/

Activated sludge without nitrogen treatment

Activated sludge with phosphorus treatment

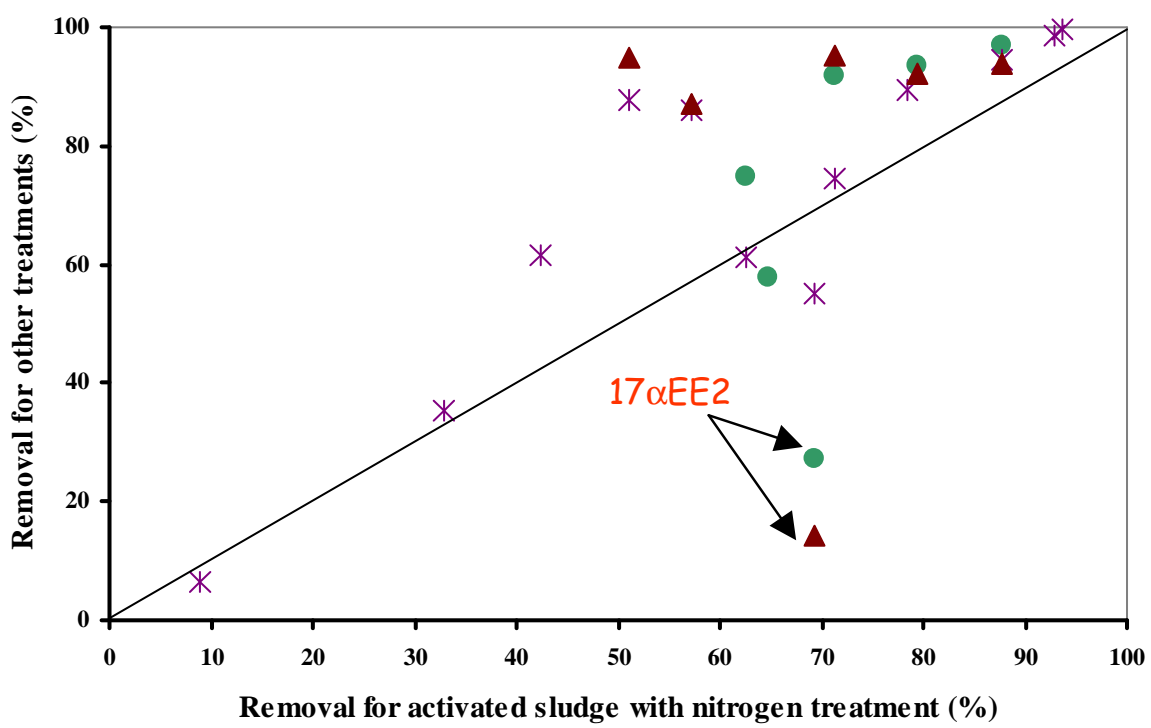

C/

Fixed biomass reactor (trickling filter, biodisc, immerged biofilter)

* Membrane bioreactor with nitrogen treatment

$\Delta$ Waste stabilization ponds

Figure 2: Comparison of removal efficiency $(\%)$ obtained for wastewater treatment plants with activated sludge process with nitrogen treatment (x-axis) and for wastewater treatment plants with other treatment processes (y-axis); each point represents mean removal calculated for one molecule. 